\title{
GREAT TRAP-DYKES AND REMAINS OF AN ANCIENT FOREST IN SKYE.
}

To the Editor of the Geological Magazine.

SiR,-Having just returned from a trip in Skye, there are two points I wish to draw the attention of your readers to. The ancient forest of the Highlands and the great trap-dykes of the district.

You favoured me last year with the insertion in your MAGAZINE of my views respecting the ancient forest. I subsequently found them, in great measure, confirmed by Mr. Geikie. I sought in vain in the peat-bogs of Skye, in the Sligachan district, amongst the Cuchullin Hills, for remains of this forest; but found them beautifully exhibited at Kyleaton. ${ }^{1}$ It is everywhere hidden under beds of peat, until the peat-diggers expose them; then the stools are seen standing up two to three feet high, so hardened by the action of bogwater, that vain is the attempt to out them, and, as a rule, they are left behind, rooted in the gravel in which they grew - the gravelbed of Scotland-here covered up with that interloper peat, in which no trees can live. I am therefore confirmed in the view before expressed, that the destruction of the ancient forest is owing to climatal changes of great antiquity. I was desirous of ascertaining the species of fir to which these stools belong. At last the quick eye of my brother, a botanist, saw the cones spread around two of the stools; the peat had preserved them as it preserves the wood, and the roots of bog-plants; they expanded, in drying, like recent cones of Scotch fir. I could discover no difference between them and recent Scotch fir, and therefore consider the trees were of the indigenous conifer of Scotland, now existing. There seems no reason why they should not be preserved in localities where peat did not grow, or where they were not exposed to the violence of the western winds.

Skye, like all other Islands of the western sea of Scotland, as shown by Sir R. Murchison's sketch-map, is chiefly composed of eruptive rocks, which consist of two kinds, the more considerable and ancient, due to that great development which raised the Cuchullins greater hills 3,200 feet at Scuir-na-Gillean, and the much later, or trap-dykes. The first of unknown primeval age, to which we may assume we owe the earliest elevation of the land above the sea; which lifted mountain ranges as well as the younger strata, modified by denudation of the ocean, and no doubt since moulded by atmospheric agencies. These major mountains of Skye are composed of what is called Hypersthene, and are distinguishable from others by their hardness, and by their aiguille points, which nothing alters. They throw down no débris from age to age, but shoot off the rains of the Atlantic at once, as from the roof of a house. The flanks of Scuir-na-Gillean present the appearance of

1 Kyle-Rhea, or Kyle Akin ?-EDrt. 
lava-currents, great sheets of which may be seen descending to the sea-shore, where they are sometimes thrown up in rugged masses, as though acted on by the sea-water when in a state of fusion, as may now be seen in Sicily.

Next to these most ancient rocks come the lower hills, whose origin we assign to a somewhat later period, when the volcanic action was dying out : these are composed of materials readily acted on by the atmosphere, and are thus shaven into cones. I must now refer to the trap dykes. Every geologist who has studied the Western Highlands well knows the great area which has been subjected to volcanic action at a comparatively late period. In the low grounds, in the beds of rivers, and on the sea shore, we find trap-dykes, from one inch to several feet in width, passing through the more ancient beds, into which various qualities of trap have been injected. This appears to me to have been the subsiding action of the great elevatory force, and it is interesting to find it extending in Scotland up to the Tertiary period, for Skye offers at Broadford most interesting examples of trap-dykes traversing the Lias limestone.

I will only add, that subsequently to the periods referred to, came that universal surface action by which all Scotland and the North of England have been covered with gravel beds-a subject deserving deep and persistent enquiry. In these beds the primeval forest grew, which, in its turn, has been buried beneath peat or soil, the surface of which is now adorned with the flora of our modern time. Yours,

Further Barton, Cirencester, Thos. C. Brown. 7 th September, 1867.

THE ORIGIN OF GRANITE.

To the Eiditor of the Geological Magazine.

Str,-I am glad to see "the origin of granite" is likely to crop up as a result of Dr. Sterry Hunt's Lecture "On the Chemistry of the Primeval Earth," which has been so ably commented on in the last number of the Geological Magazine by Mr. David Forbes. There has been so much "Denudation" of late, both marine and atmospheric, that we need not be surprised if a deep-seated rock, like granite, is laid bare, and at last appears on the surface in the field of geological discussion.

At the recent meeting of the British Association in Dundee, Professor Ansted communicated a paper "On the Conversion of Stratified Rock into Granite in the North of Corsica." I took part in the discussion which ensued; but as my remarks, together with those of Sir Charles Lyell and Mr. Geikie, were reported thus-" Some discussion followed the reading of the paper," while those of Professors Phillips and Ramsay were merely noticed, I venture to ask you to have the kindness to permit me to re-state in the pages of the Geological Magazine, as briefly as possible, the substance of what I said on that occasion. 